\title{
Android-Based High School Management Information System
}

\author{
I Wayan Adi Krisna \\ Department of Information \\ Technology \\ Faculty of Engineering \\ Udayana University \\ Badung, Bali, Indonesia
}

\author{
I Nyoman Piarsa \\ Department of Information \\ Technology \\ Faculty of Engineering \\ Udayana University \\ Badung, Bali, Indonesia
}

\author{
Putu Wira Buana \\ Department of Information \\ Technology \\ Faculty of Engineering \\ Udayana University \\ Badung, Bali, Indonesia
}

\begin{abstract}
Android is a digital platform that often used in current society. It is used by almost all communities, either youngsters or adults, including students and high school teachers. Schools generally apply a conventional way when it comes to the academic process, such as a teacher gives grades by writing them down, students manually write their schedules every semester, giving announcement by gathering the students in the hall and ask students to attend school just to take their report cards. The Android Based High School Management Information System is created to facilitate school academic process. The system can be used by the teachers and students to make the school academic process easier. Furthermore, the student guardians receive the notifications about the student attendance and grade report. This academic process can be applied anytime and anywhere as long as it is connected to the internet. The teachers can input the grades via phone, getting latest school information, seeing the given grades and schedules. The students can see their schedules, getting the latest information, seeing their grades and notifications whenever the teachers have input their grades. The student guardians can get the students attendance and grade report.
\end{abstract}

Keywords: Android, Schedule, Attendance, Grade, News, Notification.

\section{INTRODUCTION}

School is an academic institution that is important to children in the world as well as Indonesia. It is not only important to the children, but also to the parents because they also have to send their children to get proper education. School in The Great Dictionary of the Indonesian Language can be interpreted as a place or an institution for learning and teaching or a place to give and receive education. The teacher and student are the two main components in the school academic process. Without neither of those two, the process can not be done accordingly. The school has three educational stages, such as Elementary School, Secondary School, and High School. It generally applies a conventional way in performing several things related to the academic process, such as a teacher gives grades by writing them down, students manually write their schedules every semester, giving announcement by gathering the students in the hall and ask the students to attend school just to take their report cards. The obstacles related to the academic process can be solved by applying the current technology. Nowadays, information technology is developing rapidly and able to give effect to make events and activities easier. By the technology, the academic process can be much easier in both student and teacher sides. Those cases can be simplified by developing a system that can integrate them and can be easily used by the teachers and students. The application of the information system will be helpful if it is done according to the vision and mission and also the aim of the academic institution. [1]

There are some studies related to cloud computing, e-learning, and national exam tryout system that are used as references in this research. The study by Yusuf Bagas Saputro and Yos Richard Beeh with the title "Android Based Student Information System Development: Case Study of SMA Negeri 1 Tengaran (Original title: Pengembangan Sistem Informasi Kesiswaan Berbasis Android Studi Kasus SMA Negeri 1 Tengaran)" was done by developing a mobile-based application in order to display data, like credit point data and announcements [2].
The earlier study entitled "An Overview Of Cloud Computing For E-Learning With Its Key Benefits" by Mansi Bosamia and Atul Patel explains the usage of the cloud computing in elearning system and the main advantage of it in e-learning [3]. The study by Mentari Harmadya, Gusti Made Arya Sasmita, and Ni Kadek Ayu Wirdiani with the title "Design of the Android-Based Application for Junior High School National Examination (Original title: Rancang Bangun Aplikasi Try out Ujian Nasional Sekolah Menengah Pertama (Smp) Berbasis Android)" was carried out by developing an Android application that can be used by users (Secondary school students) to do the tryouts and exercises. The values and history of using the application can also be seen by the user. Meanwhile, the questions in it were inputted by the system admin [4].

The study by Mohd. Siddik and Akmal Nasution with the title "Android-based Push Notification Application Design (Original Title: Perancangan Aplikasi Push Notification Berbasis Android)" is done by creating a system to make a registration by inputting the email into the system, then it can be verified by them. Furthermore, the mobile application gives a notification to the user in a form of message entitle the content is here [5].

A study related to a cloud based application was done by Putu Satya Saputra, I Made Sukarsa, and I Putu Agung Bayupati entitled "Cloud-Based Information System for Monitoring Children Development in Kindergarten Schools (Original title: Sistem Informasi Monitoring Perkembangan Anak di Sekolah Taman Kanak-kanak Berbasis Cloud)". It performed by creating a system that could be used to monitor child development in school. It gives information to the parents, such as the lesson sources, weekly report, and also the children's report cards [6].

The study by I Kadek Kris Sanjaya, Putu Wira Buana and I Made Sukarsa with the title "Designing Mobile Transactional Based Restaurant Management" was done by developing a cloud based mobile application in order to simplify the food order in a restaurant. From ordering food to the payment can be done in the developed application [7]. 
The study by Anisa Rahmi, I Nyoman Piarsa and Putu Wira Buana with the title "FinDoctor-Interactive Android Clinic Geographical Information System Using Firebase and Google Maps Api" shows that the patient can find a doctor through their phones. Then, they will get the queue number and it will be updated by the real-time doctor or doctor's assistant. The use of firebase in this application is to send a notification in real-time to the patient's phone, therefore they do not have to wait too long in the clinic [8].

The earlier study by Salamun titled "Android-Based Student Value Monitoring System (Original title: Sistem Monitoring Nilai Siswa Berbasis Android)" was done by creating an Android based system which contains the grade data, student council data, attendance data, achievement information, and also violation information. [9]

According to the mentioned studies above, those studies can be used as the references in making this study. The Android Based High School Management Information System has an innovation in Android based system, therefore it can be easier to use as long as it is connected to the internet. In addition, in the schedules that are directed to both teacher and student to simplify the schedule management and the grade notification to the student. Therefore, if the teacher has input the grades, the student can be instantly informed and their guardians can also receive the notification about the attendance of the student in class and the grade that is inputted by the teacher.

\section{LITERATURE REVIEW}

This literature Review discusses about supporting theories in conducting the study, such as Android, Android Studio, Database, MySQL, SQLyog, Firebase, Web service and Cloud computing.

\subsection{Android}

Android is a developed operating system for Linux-based mobile devices such as smart phones and tablet computers. In 2005, it has been bought by Google after being developed by Android. Inc. It was officially released on November 5, 2007 and followed by Google that released the codes on Android under the Apache license. The Android operating system is an open source and anyone can develop Android applications.

\subsection{Android Studio}

Android Studio is a platform or an Integrated Development Environment (IDE) to create or develop an Android-based application. It is the official software from Google that was released in 2013 for developers who specifically want to develop an Android application. It is available for three OS platforms, including Windows, Linux and Mac. Android Studio is not the only platform to develop Android apps, but it is more used because it is an official application from Google, therefore there are many tutorials in Android application development by using it.

\subsection{Database}

The database is the collections of some data that are related and stored on the computer, also can be processed to generate information. The database is needed for creating an information system, because there are a lot of data that needed to be integrated in order to avoid data manipulation. It has several functions, such as classifying data accordingly therefore data duplication will not occur; helping to simplify the process of deleting data, editing data and adding data; it is capable of storing large and numerous data, therefore the system will be maintained and integrated well. In developing a computer based database system, it requires a software called DMBS (Database Management System). DBMS helps to facilitate database users in order to be able to integrate databases in an information system. It also helps in processing large amounts of data, therefore the users can use it based on their needs. There are several database softwares such as MySQL, Microsoft Access, Oracle, Firebird, Microsoft SQL Server, and Fisual FoxPro 6.0.

\subsection{MySQL}

MySQL is one of several Database Management System (DBMS) softwares for computerized database management by using SQL (Structured Query Language). SQL is a special language used for accessing data in the database and MySQL is a database software to run and access the MySQL database by using the Structured Query Language (SQL) itself. It is an open source software that is often used in database management as well as for building a system. Also, it has high reliability, although it is an open source. MySQL can process very large and complex data, even many big companies use their databases such as, New York Times, Wikipedia, Google, and Facebook. It is already purchased and managed by one of the world's largest software management companies, Oracle.

\subsection{SQLyog}

SQLyog is a software or application used to run MySQL databases. It is a widely used software because it has a user friendly and easy to use compared to phpMyAdmin. The main function of SQLyog is actually the same as phpMyAdmin, which is to manage the MySQL database except that there are several other features that are not in phpMyAdmin.

\subsection{Firebase}

Firebase is one of the official services from Google that was released to help developers simplify the development of applications they create. It is a cloud based realtime database service that is widely used by developers. In addition, it provides several services, one of them is Firebase Cloud Messaging (FCM). FCM is one of the features or services provided by Firebase that is used to send realtime notification messages via the same platform or across platforms. It helps in giving message notifications to the current developers in developing their application, because users need fast and realtime information. Therefore, FCM is widely applied to the existing applications. It has a key ability to send both notification messages and data messages, versatile message targeting, and messages from client applications. Firebase Cloud Messaging (FCM) can be implemented by providing two components, such as to create, target and send messages, also to receive messages.

\subsection{Web Service}

Web Service is a software that serves as a link to exchange data or information between a system and application. It is needed because every system or application that wants to do the data exchange is made by different programming languages or platforms. XML format is used by it which is a standard format to exchange data in various systems or applications for various platforms. Web service manipulates the databases' data, then from the manipulated data, it generates an XML format that is a standard data exchange format and connects it to other systems or applications. It is currently used for applications that have two different kinds of platform types, such as Android and web. 


\subsection{Cloud Computing}

Cloud computing or in Bahasa Indonesia means komputasi awan is a computerized technology where the services and data of a system or application are no longer stored in a single local computer, but rather stored virtually on the Internet. Therefore, it can be accessed through many platforms and easier to share. According to the National Institute of Standards and Technology (NIST), Cloud Computing is a technological innovation that provides configurable computing needs and resources minimum interaction. It works online on the internet as a server to process data and then can be accessed by connecting computers. Also, it is currently used by world's technology companies such as Apple, Google, Microsoft and the others.

\section{RESEARCH METHODS}

There are some steps in conducting this study. The stages can be seen in Figure 1.

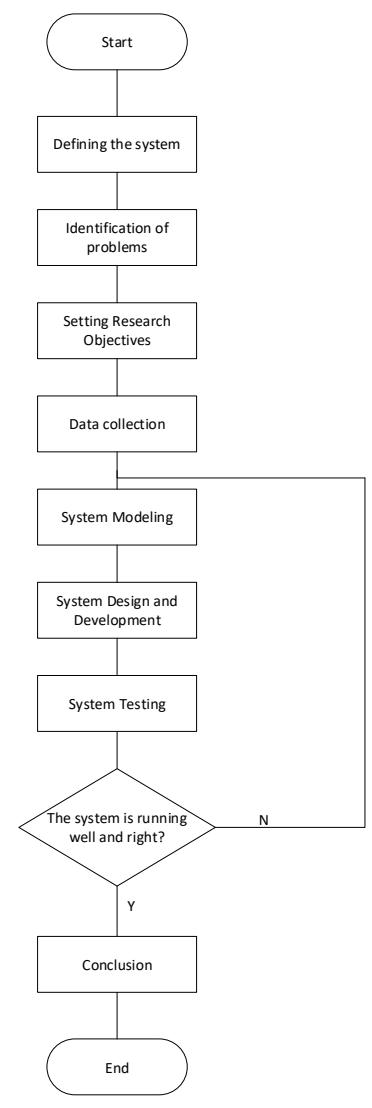

Figure 1. Research phase

The first step is to define the developed system, then identify problems related to the study. The second step is to set study objectives, therefore the readers can understand the purpose of the study. The next step is to collect the data required for the study. If the data have completed, then creating the modeling system to figure the initial image of the system. Then, designing and developing the system, including the database design and system forming. Lastly, testing the system and drawing the conclusions from the whole system.

\subsection{General Overview of the System}

The study of Android-based high school management information system application has an overview that can be seen in Figure 2.

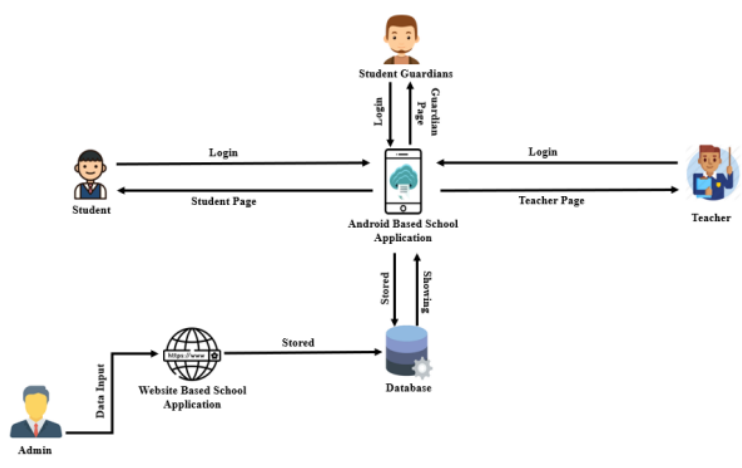

Figure 2. System Overview

The system workflow starts with the new accepted student at school, the admin of the website registers them, then they get a username and password to access the school SIM application. Student guardians also can enter the system by using the username and password that obtained by the students in the school. Teachers are also registered by the system admin and get their username and password to access the school SIM application. After the student login, there are other menu will be displayed in the main menu of daily lesson schedules, such as profile, school grades and news. The profile menu contains student profile, photos, and personal data as well as the parents' data. The school grade menu contains the data of the subjects that is taken by the students. The news menu contains the latest news from the school that is displayed on the login or can be read in the News menu. The main menu contains the schedules of subjects that taken by students from Monday to Saturday, completed with the name of the subjects, the name of teachers as well as the times of the lesson. The students can upload a permission letter if they could not attend a class on a particular day.

The student guardians have several menus which include profile, student grades data and student attendance. The profile menu contains the personal data of the student's parent or guardian. The student grades data contains the grades that obtained by the students, meanwhile the attendance contains the attendance data from the student. The parents or guardians can receive a notification if the teacher has given the scores and if the teacher has done the student attendance check, therefore they no longer need to worry about their children not attending the class.

The teachers have several menus which include schedule as the main menu, profile, grades, add grades, change school and news. Schedule as the teacher's main menu contains the teaching schedule from Monday to Saturday along with the subject name, the time, the name of school where they have to teach and the classrooms. The profile contains the teacher's personal data and education history. Grades, on the teacher's grades menu displays the grades data that already given to each student per class as well as the subject. The Add Grades menu contains the grade input process by the teacher who can be done per class and the subjects. In addition, homeroom teachers can do a verification therefore other teachers who have given the grades cannot change them again and the assessment authority can be given to them. The Change School is a menu that is used to transfer from school A to school B because in this system, the teachers are able to teach in several schools. Therefore, this menu is provided to transfer 
schools. The News menu contains the latest news from the school.

\subsection{Context Diagram}

The diagram context is the most basic level in the data flow diagram, which describes only one process that is the overall system creating process. The diagram context of the Androidbased high school management information system will be described in Figure 3.

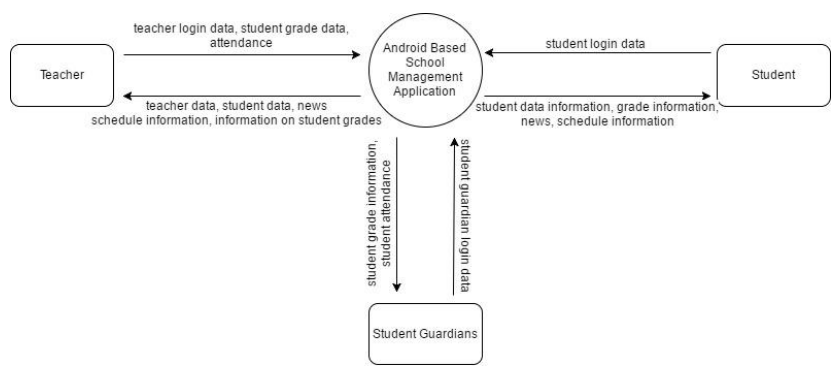

Figure 3. System Context Diagram

Figure 3 is the diagram context of the Android-based high school management information system where there are three user systems: teacher, student and student guardian. The process that occurs, such as teacher can login into the system. After that, they can add grades and do attendance check to students. The exchange that provided by the system is their data after they do a login, the data of the students used by the teachers to input grades, the list of grades that the teacher has input, their news and schedule information who has been input by the admin. The students can login to the system. Then, the system gives the student data information, grade information, lesson schedule information and also news. The guardians can login into the system by using the NISN username and password of the student, then the system gives the student grade information and student attendance.

\section{RESULT AND DISCUSSION}

The results and discussion of the Android based high school management information system includes three users, namely teachers, students and guardians.

\subsection{Teacher}

The teacher has several features that can be used on an Android-Based High School Management Information System (a)

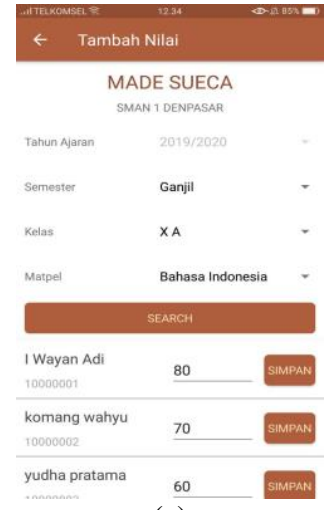

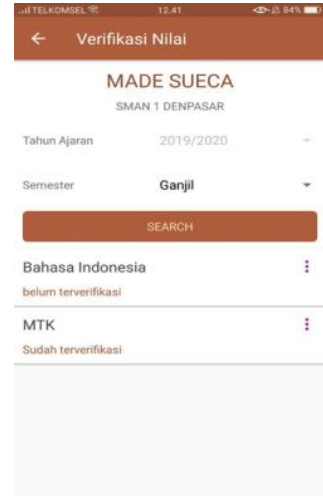

(b)
Figure 4. Add grades and view grades Menu.
Figure 4. (a) shows the display of the add grades menu that is used by the teachers in giving grades to the students according to the subject, class, semester, and the active academic year. The teachers can assign the grades by choosing what subjects they want to input, then the class that they taught and selecting the semester. The active academic year automatically displays. After that, they can enter the grade of each student and press save to finish it. The grades that entered by them go to the homeroom teacher. Then, the homeroom can re-edit each student's grade and verify them so they cannot be changed by the teacher who gave the grades earlier. It can be seen in Figure 4. (b).

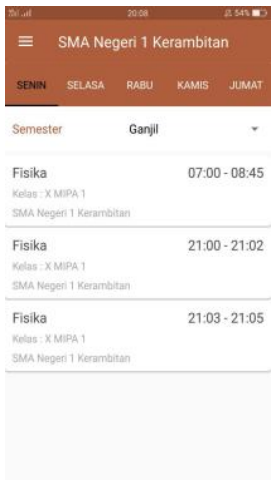

(a)

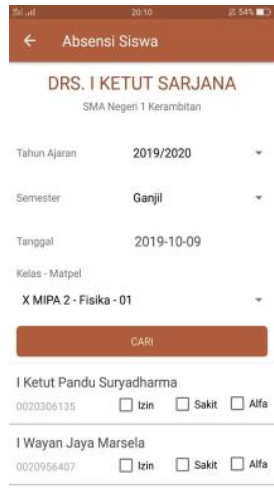

(b)
Figure 5. Teacher schedule and Attendance

Figure 5. (a) shows a display of the teacher's main menu in the form of a schedule on the Android-based high school management information System application. The schedule is the main menu of the teacher. They can see the teaching schedules on the display, followed by the subjects that taught by them, the class, the time, and the school where they have to teach. Fig. 5. (b) shows the display of the teacher's attendance menu. The teachers can do attendance check based on dates, classes, and subjects. They can see the permit or sick letters of the students before the attendance check. The parents or guardian of the student will receive a notification about the student's attendance report if they are present or absent in class.

\subsection{Student}

The students have several features that can be used on an Android-based high school management information System.

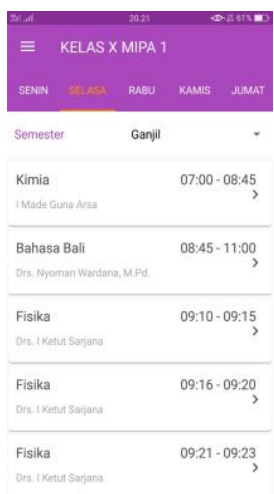

(a)

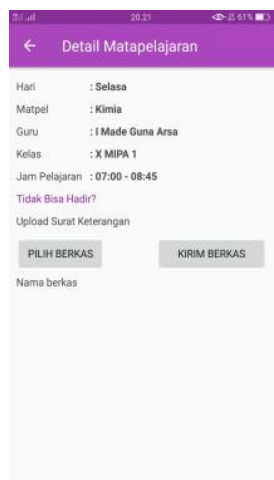

(b)
Figure 6. Student schedule

Figure 6. (a) shows a display of the student's main menu in the form of a schedule on Android-based high school 
management information System application. The schedule is the main menu for students. They can see the timetable from Monday to Saturday as well as the relevant teachers at the schedule, subjects and time. Figure 6. (b) shows a display of the subject details that used by the students to upload a permission letter if they are unable to attend to the particular subject. The letter will be seen by the teacher during the attendance check.

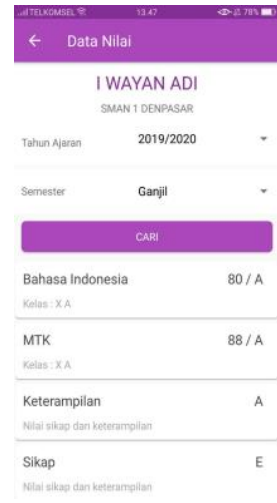

(a)

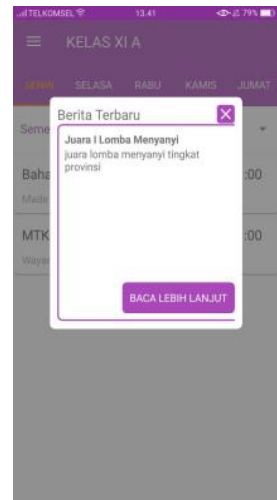

(b)
Figure 7. Student grades and latest Pop-up News

Figure 7. (a) shows a display of student grades data in the Android-based high school management application, where the grades data menu displays the grades that have been given by the teacher of the subjects taken. In order to see their grades, the students select the semester and then the academic year. They can see their grades in the odd and even semesters based on the academic year. Fig. 7. (b) shows the latest popup information display of the student menu. The students who have logged in to the application are shown a pop-up information that contains the latest information from the school. The displayed Pop-up information contains the title and the info preview. The students can directly read the information if they have some time, but they can also read it later on the news menu that has been provided.

\subsection{Student Guardian}

The student guardian has several features that can be used on an Android-based high school management information System.

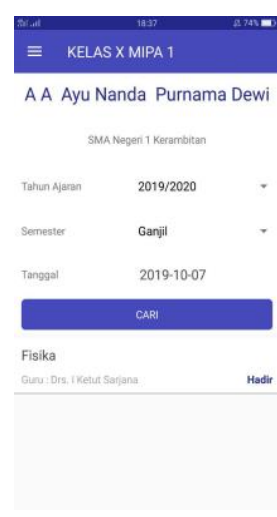

(a)

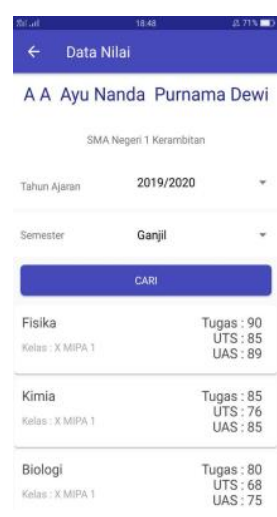

(b)
Figure 8. Attendance Report and Student grades
Figure 8. (a) shows the student attendance report for the student's guardian. The guardian will receive a notification if the teacher has done the class attendance check. The notification contains a notice that the student is present or absent in class. The Grade Report contains the grades that already received by the student.

\section{CONCLUSION}

The Android Based High School Management Information System is the application that was created to manage high school academic process. This application can be used by three different users: teachers, students, and student guardian. The teacher has several features that can be used in the application, such as teaching schedule reminder, pop-up information to display the latest school news, attendance, etc. The student in this application has several features, such as lesson schedule reminder, a place to upload the permission letter when they are unable to attend class, pop-up information, and the notification when the teacher has input the grades. The student guardian has two main features which, such as a notification of student attendance in order to know if the student is present or absent and a notification when the teacher has input the student grades.

\section{REFERENCES}

[1] K. Imtihan, "Perencanaan Strategi Sistem Informasi Pendidikan Pada Sekolah Tinggi Manajemen Informatika dan Komputer ( STMIK ) Lombok," vol. 3, no. 2, pp. 73-78, 2015.

[2] Y. R. Beeh, "Pengembangan Sistem Informasi Kesiswaan Berbasis Android Studi Kasus SMA Negeri 1 Tengaran Artikel Ilmiah," no. 672012228, 2016.

[3] M. Bosamia, A. Patel, and Chandaben, "An Overview of Cloud Computing for E-Learning With Its Key Benefits," Int. J. Inf. Sci. Tech., vol. 6, no. 1, pp. 1-10, 2016.

[4] M. Harmadya, G. M. Aryasasmita, N. Kadek, and A. Wirdiani, "Rancang Bangun Aplikasi Tryout Ujian Nasional Sekolah Menengah Pertama ( Smp ) Berbasis Android," vol. 6, no. 2, pp. 108-119, 2015.

[5] M. Siddik and A. Nasution, "Perancangan Aplikasi Push Notification," vol. IV, no. 2, 2018.

[6] P. S. Saputra, I. M. Sukarsa, and I. P. A. Bayupati, "Sistem Informasi Monitoring Perkembangan Anak di Sekolah Taman Kanak - kanak Berbasis Cloud," vol. 8, no. 2, pp. 112-123, 2017.

[7] I. K. K. Sanjaya, P. W. Buana, and I. M. Sukarsa, "Designing Mobile Transactional Based Restaurant Management," vol. 11, no. 6, pp. 130-136, 2019.

[8] A. Rahmi, I. N. Piarsa, and P. W. Buana, "FinDoctor Interactive Android Clinic Geographical Information System Using Firebase and Google Maps API," no. 7, pp. 8-12, 2017.

[9] Salamun, "Sistem Monitoring Nilai Siswa Berbasis Android," Rabit, vol. 2, no. 2, pp. 211-219, 2017. 